\title{
DEGRADASI ZAT WARNA KONGO MERAH LIMBAH CAIR INDUSTRI TEKSTIL DI KABUPATEN PEKALONGAN MENGGUNAKAN METODE ELEKTRODEKOLORISASI
}

\author{
Suyata dan Mardiyah Kurniasih \\ Program Studi Kimia, MIPA, Fakultas Sains dan Teknik, Unsoed, Purwokerto \\ email: suyatab@gmail.com
}

\begin{abstract}
ABSTRAK
Degradasi zat warna kongo merah limbah cair industri tekstil menggunakan metode elektrodekolorisasi telah dilakukan. Eksperimen dilakukan dengan mengelektrolisis kongo merah menggunakan katoda karbon dan anoda besi. Analisis konsentrasi kongo merah dilakukan menggunakan metode spektrofotometri. Hasil penelitian menunjukkan bahwa dibawah kondisi optimum pada voltase $12 \mathrm{~V}$ - jarak elektroda $1 \mathrm{~cm}-\mathrm{pH}$ 4- konsentrasi $\mathrm{H}_{2} \mathrm{O}_{2} 500 \mathrm{mg} / \mathrm{L}$ selama 12 menit, zat warna kongo red limbah cair industri tekstil dapat didegradasi 99,83\%. Metode ini dapat digunakan untuk mendegradasi zat warna kongo merah.
\end{abstract}

Kata kunci : kongo merah, metode elektrodekolorisasi, limbah cair industri tekstil

\section{DEGRADATION OF CONGO RED DYE OF TEXTILE INDUSTRIAL WASTEWATER AT PEKALONGAN REGENCY USING ELECTRODECOLORIZATION METHOD}

\begin{abstract}
Degradation of congo red dye of textile industrial wastewater using electrodecolorization method has been done. The experiment have been performed by electrolysis of congo red using carbon cathode and iron anode. Analysis of congo red concentration using spectrophotometric method. The result of the research showed that under the optimum conditions of $12 \mathrm{~V}$ voltage $-1 \mathrm{~cm}$ electrode distance $-\mathrm{pH} 4-500 \mathrm{mg} / \mathrm{L}$ $\mathrm{H}_{2} \mathrm{O}_{2}$ for 12 minutes, congo red dye of textile industrial wastewater can be degraded $99.83 \%$. This method can be applied to degradation of congo red dye.

Keywords: congo red, electrodecolorization method, textile industrial wastewater

PENDAHULUAN

Salah satu sumber pendapatan daerah Pekalongan berasal dari industri tekstil. Keberadaan industri tekstil ini disamping mempunyai dampak positif terhadap daerah, berupa peningkatan pendapatan daerah, juga mempunyai

dampak negatif, yaitu timbulnya pencemaran lingkungan.

Limbah cair industri tekstil terutama dihasilkan dari proses pewarnaan (dyeing). Limbah cair yang dihasilkan dari proses ini menyebabkan pencemaran lingkungan karena dibuang ke badan perairan tanpa pengolahan
\end{abstract}


terlebih dahulu. Badan perairan tidak mampu mendegradasi zat warna tersebut sehingga daerah aliran sungai menjadi berwarna dan tidak dapat mendukung sistem kehidupan perairan.

Zat warna reaktif merupakan zat warna yang banyak digunakan untuk pewarnaan tekstil (Robinson et al.,2001). Kongo merah merupakan salah satu zat warna reaktif yang sering digunakan industri tekstil. Zat warna tersebut sangat larut dalam air dan tidak dapat terdegradasi secara biologi (recalcitrance) (Catanho, 2006).

Beberapa metode degradasi zat warna telah dikembangkan, misalnya dengan cara fotokatalisis dengan $\mathrm{TiO}_{2}$ (Rashed dan El-Amin, 2007). Secara biologi, koagulasi, adsorpsi dengan karbon aktif (Mondal, 2008). Namun, masing-masing metode penggunaannya terbatas dan kurang menguntungkan. Sebagai contoh, penggunaan reaksi fotokatalisis membutuhkan biaya yang cukup tinggi karena harga $\mathrm{TiO}_{2}$ cukup mahal, selain itu diperlukan perlakukan lebih lanjut terhadap $\mathrm{TiO}_{2}$ setelah proses dekolorisasi zat warna selesai. Degradasi zat warna dengan proses biologi seringkali tidak memuaskan karena zat warna mempunyai sifat tahan terhadap degradasi biologi. Cara koagulasi memiliki efisiensi yang baik dalam pengolahan limbah tetapi juga menimbulkan limbah baru yaitu koagulan yang tidak dapat digunakan lagi. Penggunaan karbon aktif untuk degradasi zat warna juga memerlukan biaya yang cukup tinggi karena harga karbon aktif relatif mahal. Suatu metode degradasi zat warna yang lebih efektif, efisien dan murah perlu dikembangkan, yaitu metode elektrodekolorisasi.

Metode elektrodekolorisasi merupakan suatu proses elektrokimia untuk menghilangkan zat warna dengan menggunakan arus listrik searah. Katoda sel elektrokimia ini adalah batang karbon yang berasal dari baterai bekas dan anodanya dari besi. Besi hidroksida terhidrat yang terbentuk sebagai hasil oksidasi anoda besi selama proses elektrolisis dapat mengadsorbsi zat warna melalui pembentukan kompleks antara permukaan besi hidroksida dengan zat warna. Zat warna diasumsikan sebagai ligan (L) yang terikat pada besi hidroksida, produk elektrodekolorisasi berupa senyawa kompleks dan air $\left(\mathrm{H}_{2} \mathrm{O}\right)$ yang ramah terhadap lingkungan.

Adapun mekanismenya sebagai berikut :

$$
\mathrm{L}-\mathrm{H}+(\mathrm{HO}) \mathrm{OFe} \longrightarrow \text { (Ibanez } \text { et al., } 1998)
$$

Berdasarkan hasil penelitian Ibanez et al. (1998), metode elektrodekolorisasi dapat digunakan untuk mendegradasi zat warna Timol Biru hingga 100\%. Gupta et al. (2007), menggunakan metode elektrodekolorisasi untuk mendegradasi zat warna berbahaya Rektofix Merah 3. Hasil penelitian Suyata dkk. (2010), metode elektrodekolorisasi dapat mendegradasi zat warna Proksion Merah MX-8B hingga 98,58\%.

Berdasarkan hal tersebut, telah dilakukan penelitian untuk mendegradasi zat warna kongo merah limbah cair industri tekstil dengan menggunakan metode elektrodekolorisasi.

\section{METODE PENELITIAN Alat dan Bahan}

Peralatan yang digunakan dalam penelitian ini adalah: besi spiral, karbon dari batu baterai ukuran AA, alat gelas, filler, kertas saring, aluminium foil, timbangan analitik, pH-meter, adaptor, spektrofotometer UV-Vis 1601 SA.

Bahan yang digunakan dalam penelitian ini adalah: natrium hidroksida, 
natrium bisulfat, asam sulfat pekat, zat warna kongo merah, hidrogen peroksida $30 \%$ dan akuades.

\section{Prosedur Penelitian}

\section{Penentuan panjang gelombang maksimum}

Larutan kongo merah $5 \mathrm{mgL}^{-1}$ diukur pada panjang gelombang 410 sampai $700 \mathrm{~nm}$. Panjang gelombang pada serapan maksimum digunakan untuk pengukuran dalam penelitian ini.

\section{Pembuatan kurva kalibrasi standar}

Larutan standar zat warna kongo merah 5; 10; 15: 20 dan $25 \mathrm{mgL}^{-1}$ diukur absorbansinya dengan spektrofotometer visible. Kurva kalibrasi dibuat dengan memplotkan antara konsentrasi (X) dengan absorbansi (Y). Dari kurva kalibrasi diperoleh persamaan regresi $\mathrm{y}=\mathrm{a}+\mathrm{bx}$. Persamaan regresi ini digunakan untuk menentukan konsentrasi dari zat warna kongo merah.

\section{Penentuan voltase optimum}

Sebanyak $40 \mathrm{~mL}$ larutan zat warna kongo merah $20 \mathrm{mg} / \mathrm{L}$ dimasukkan ke dalam gelas piala, kemudian ditambah $0,71 \mathrm{~g} \mathrm{Na}_{2} \mathrm{SO}_{4}, 4 \mathrm{~mL} \mathrm{H}_{2} \mathrm{O}_{2} 300 \mathrm{mg} / \mathrm{L}$ dan $\mathrm{H}_{2} \mathrm{SO}_{4}$ 0,8 N sampai pH 3. Absorbansi diukur untuk mendapatkan nilai absorbansi sebelum elektrolisis. Besi spiral dimasukkan ke dalam sel elektrolisis sebagai anoda dan batang karbon sebagai katoda dengan jarak $1 \mathrm{~cm}$ dan dihubungkan dengan sumber arus DC dimulai pada voltase yang paling kecil sampai besar yaitu 3, 5, 7, 9, 11, 12 dan 13 volt, kemudian dielektrolisis selama 5 menit. Larutan disaring dan diukur absorbansinya setelah proses elektrolisis selesai. Voltase yang menunjukkan persentase dekolorisasi maksimal digunakan dalam penelitian ini.

\section{Penentuan waktu optimum}

Penentuan waktu optimum dilakukan dengan kondisi larutan sama seperti penentuan voltase optimum, dengan memvariasikan waktu elektrolisis. Variasi waktu adalah 1, 3, 5, 7, 9, 11, 12, 13 dan 15 menit. Waktu yang menghasilkan persentase dekolorisasi maksimum digunakan dalam penelitian.

\section{Penentuan jarak elektroda optimum}

Sebanyak $40 \mathrm{~mL}$ larutan zat warna kongo merah $20 \mathrm{mg} / \mathrm{L}$ dimasukkan ke dalam gelas piala; kemudian ditambah $0,71 \mathrm{~g} \mathrm{Na}_{2} \mathrm{SO}_{4} ; 4 \mathrm{~mL}$ $\mathrm{H}_{2} \mathrm{O}_{2} 300 \mathrm{mg} / \mathrm{L}$ dan $\mathrm{H}_{2} \mathrm{SO}_{4}$ 0,8 N sampai $\mathrm{pH} 3$, setelah itu absorbansi larutan diukur. Besi spiral dimasukkan ke dalam sel elektrolisis sebagai anoda dan batang karbon sebagai katoda dengan jarak antara anoda dan katoda $0,5 \mathrm{~cm}$, kemudian dielektrolisis pada waktu dan voltase optimum. Larutan hasil elektrolisis disaring dan ditentukan absorbansinya dengan menggunakan spektrofotometer visible. Perlakuan diulangi untuk jarak elektroda $1,1,5 \mathrm{~cm}$ dan $2 \mathrm{~cm}$.

\section{Penentuan pH optimum}

Larutan zat warna kongo merah $20 \mathrm{mg} / \mathrm{L}$, sebanyak $40 \mathrm{~mL}$ dimasukkan ke dalam gelas piala,kemudian ditambah $0,71 \mathrm{~g} \mathrm{Na}_{2} \mathrm{SO}_{4} ; 4 \mathrm{~mL} \mathrm{H}_{2} \mathrm{O}_{2} 300 \mathrm{mg} / \mathrm{L}$ dan $\mathrm{H}_{2} \mathrm{SO}_{4}$ 0,8 N sampai $\mathrm{pH} \mathrm{3}$, setelah itu absorbansi larutan diukur. Larutan dipindahkan ke dalam sel elektrolisis dengan jarak elektroda optimum, kemudian dielektrolisis pada waktu dan voltase optimum. Larutan hasil elektrolisis disaring dan ditentukan absorbansinya dengan menggunakan spektrofotometer visible. Perlakuan diulang untuk larutan kongo merah dengan $\mathrm{pH}$ 2, 3, 4, 5, 7 dan 9 . 


\section{Penentuan konsentrasi hidrogen peroksida optimum}

Sebanyak $40 \mathrm{~mL}$ larutan zat warna kongo merah $20 \mathrm{mg} / \mathrm{L}$ dimasukkan ke dalam gelas piala. Kemudian ditambah $0,71 \mathrm{~g} \mathrm{Na}_{2} \mathrm{SO}_{4} ; 4 \mathrm{~mL} \mathrm{H} \mathrm{O}_{2} 300 \mathrm{mg} / \mathrm{L}$ dan $\mathrm{H}_{2} \mathrm{SO}_{4} \quad 0,8 \mathrm{~N}$ sampai $\mathrm{pH}$ optimum, kemudian diukur absorbansinya. Larutan dipindahkan ke dalam sel elektrolisis dengan jarak elektroda optimum, kemudian dielektrolisis pada waktu dan voltase optimum. Larutan hasil elektrolisis disaring dan ditentukan absorbansinya dengan menggunakan spektrofotometer visible. Cara yang sama dilakukan juga untuk larutan kongo merah dengan konsentrasi $\mathrm{H}_{2} \mathrm{O}_{2} 200$ $\mathrm{mg} / \mathrm{L} ; 400 \mathrm{mg} / \mathrm{L} ; 500 \mathrm{mg} / \mathrm{L} ; 700 \mathrm{mg} / \mathrm{L}$ dan $900 \mathrm{mg} / \mathrm{L}$.

\section{Penentuan persentase dekolorisasi sampel limbah cair tekstil}

Sebanyak $40 \mathrm{~mL}$ sampel limbah cair tekstil dimasukkan ke dalam gelas piala, kemudian ditambah dengan $0,71 \mathrm{~g}$ $\mathrm{Na}_{2} \mathrm{SO}_{4}$ : $4 \mathrm{~mL} \mathrm{H}_{2} \mathrm{O}_{2}$ dengan konsentrasi optimum dan $\mathrm{H}_{2} \mathrm{SO}_{4} 0,8 \mathrm{~N}$ sampai $\mathrm{pH}$ optimum, kemudian diukur absorbansinya pada panjang gelombang maksimum. Larutan dipindahkan ke dalam sel elektrolisis dengan jarak elektroda optimum, kemudian dielektrolisis pada waktu optimum dan voltase optimum. Larutan hasil elektrolisis disaring dan ditentukan absorbansinya dengan menggunakan spektrofotometer visible.

\section{HASIL DAN PEMBAHASAN}

\section{Penentuan Panjang Gelombang Maksimum}

Panjang gelombang maksimum larutan zat warna kongo merah pada $503 \mathrm{~nm}$. Hal ini disebabkan warna merah adalah warna komplementer dari warna hijau yang diserap pada panjang gelombang antara 490-560 nm (Skoog et al., 2004).

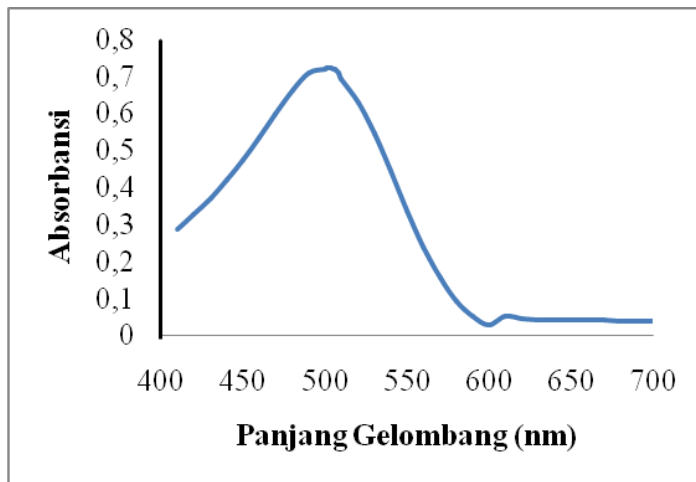

Gambar 1. Spektrum absorbsi kongo merah

Panjang gelombang maksimum dari zat warna kongo merah ini kemudian digunakan untuk pengukuran absorbansi larutan sampel sebelum dan sesudah proses elektrodekolorisasi.

\section{Pembuatan Kurva Kalibrasi}

Kurva kalibrasi dibuat dengan cara memplotkan antara konsentrasi larutan standar (sumbu $\mathrm{X}$ ) dengan absorbansi (sumbu Y), kemudian dari kurva kalibrasi akan didapatkan suatu persamaan regresi yang digunakan untuk menghitung konsentrasi sampel yang tersaji pada Gambar 2.

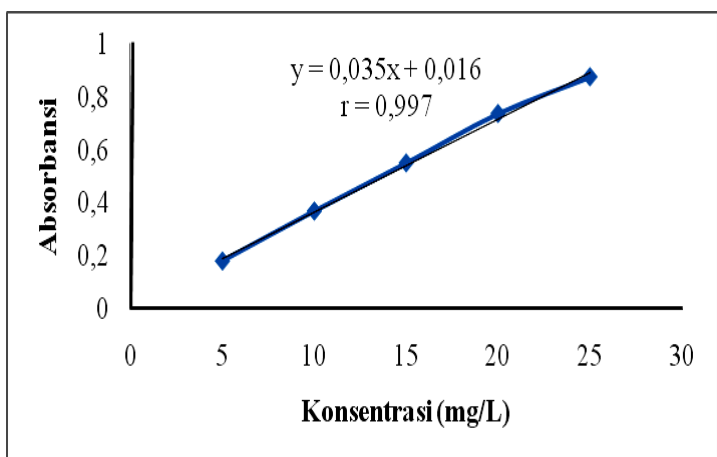

Gambar 2. Kurva kalibrasi larutan zat warna kongo merah

Persamaan regresi yang diperoleh untuk zat warna kongo merah adalah 
$\mathrm{y}=0,035 \mathrm{x}+0,016$ dengan koefisien korelasi 0,997.

\section{Penentuan Voltase Optimum}

Voltase optimum merupakan voltase dimana persentase dekolorisasi larutan zat warna kongo merah mencapai nilai maksimal. Proses elektrolisis larutan dikerjakan dengan melakukan variasi voltase tiap larutan. Rentang potensial ini menggambarkan jumlah besar energi yang setara dengan energi yang diperlukan untuk proses transfer elektron berlangsung. Besar dan lebar rentang potensial ini bersifat khusus untuk setiap pelarut dan dalam penerapannya bergantung pula pada komposisi sistem elektrolit pendukung dan sifat alami elektroda kerja besi (Ibanez et al., 1998).

Voltase optimum dekolorisasi kongo merah dapat dilihat pada Gambar 3.

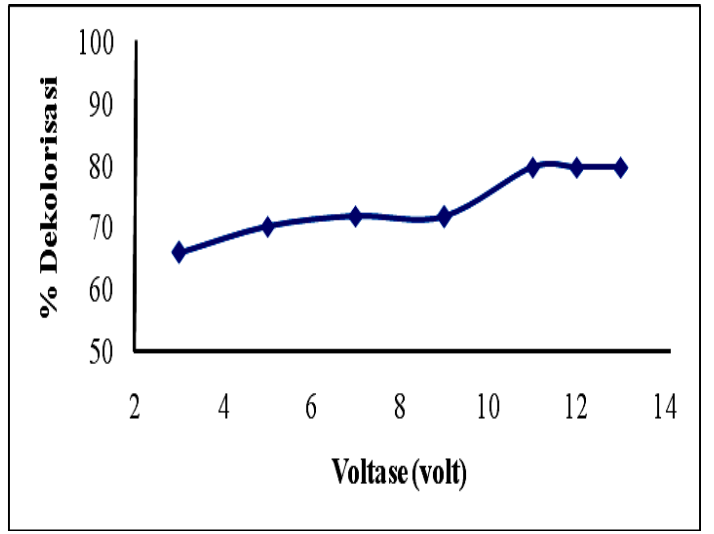

Gambar 3. Grafik pengaruh voltase terhadap \% dekolorisasi kongo merah

Persentase dekolorisasi kongo merah mencapai optimum pada voltase 12 volt dengan nilai persentase dekolorisasi 79,83\%. Menurut Ibanez et al. (1998), kondisi optimum disebabkan oleh pemberian ion $\mathrm{Fe}^{3+}$ dari anoda ke katoda sangat besar sehingga terjadi kesetimbangan pembentukan ion kompleks antara zat warna dengan besi hidroksida $\left(\mathrm{Fe}(\mathrm{OH})_{3}\right)$ yang akan menyebabkan kekuatan ion dan kepekatan larutan mencapai maksimal.

\section{Penentuan Waktu Optimum}

Waktu optimum merupakan waktu yang diperlukan untuk proses dekolorisasi zat warna kongo merah secara maksimal. Waktu optimum dekolorisasi kongo merah dapat dilihat pada Gambar 4.

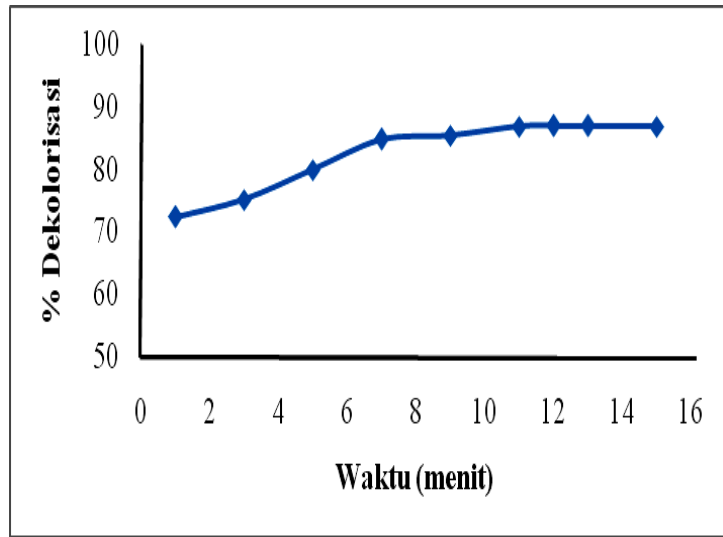

Gambar 4. Grafik pengaruh waktu terhadap \% dekolorisasi kongo merah

Berdasarkan Gambar 4 menunjukkan bahwa persentase dekolorisasi kongo merah mencapai optimum pada waktu 12 menit dengan nilai persentase dekolorisasi mencapai $86,90 \%$. Hal ini terjadi karena radikal $\mathrm{OH}$ tidak terbentuk lagi pada waktu dekolorisasi lebih dari waktu dekolorisasi optimum (Suprijono, 2004).

\section{Penentuan Jarak Elektroda Optimum}

Jarak elektroda optimum adalah jarak antara anoda dan katoda yang dapat mendekolorisasi zat warna kongo merah secara maksimum. Elektrolisis dilakukan dengan menggunakan anoda besi dan katoda karbon dengan berbagai macam variasi jarak elektroda yaitu 0,$5 ; 1 ; 1,5$; dan $2 \mathrm{~cm}$ pada voltase optimum

Berdasarkan hasil penelitian seperti terlihat pada Gambar 5 
menunjukkan bahwa jarak elektroda optimum dari kongo merah dicapai pada jarak $1 \mathrm{~cm}$ dengan persentase dekolorisasi sebesar 86,90\%.

Pada jarak elektroda optimum, gas hidrogen $\left(\mathrm{H}_{2}\right)$ yang dihasilkan oleh katoda selama proses elektrolisis mengenai permukaan anoda lebih merata, hal ini dapat mempercepat proses pengapungan dan pengumpulan flok-flok besi hidroksida $\mathrm{Fe}(\mathrm{OH})_{3}$ yang dihasilkan selama proses elektrolisis sehingga proses dekolorisasi mencapai maksimal (Ibanez et al., 1998).

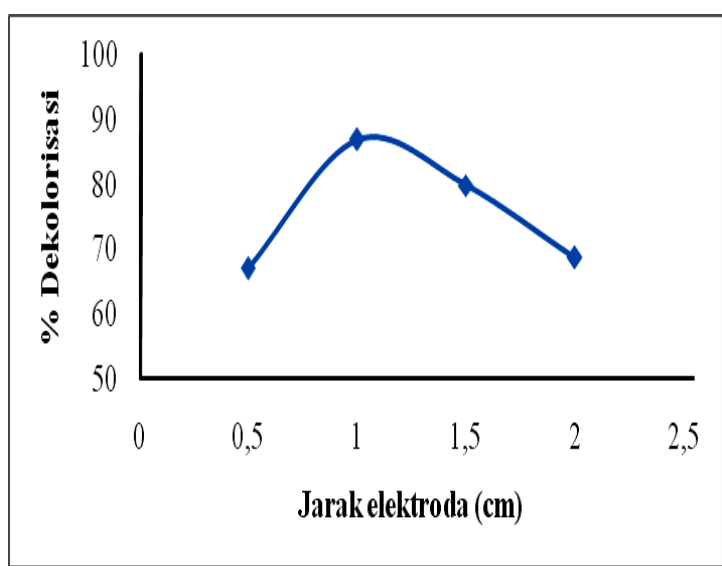

Gambar 5. Grafik pengaruh jarak elektroda dengan persentase dekolorisasi kongo merah

\section{Penentuan pH Optimum}

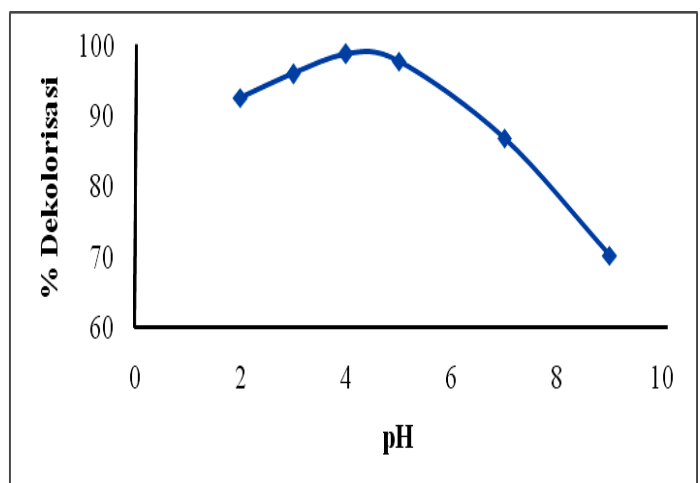

Gambar 6. Grafik pengaruh $\mathrm{pH}$ terhadap $\%$ dekolorisasi kongo merah

Penentuan $\mathrm{pH}$ optimum pada dekolorisasi kongo merah dilakukan dengan memvariasikan $\mathrm{pH}$ larutan pada voltase dan jarak elektroda optimum. $\mathrm{pH}$ larutan mempengaruhi keefektifan $\mathrm{H}_{2} \mathrm{O}_{2}$ dalam menghasilkan radikal $\mathrm{OH}$ yang dikatalisis oleh $\mathrm{Fe}^{2+}$. $\mathrm{pH}$ optimum dekolorisasi kongo merah dapat dilihat pada Gambar 6.

Berdasarkan Gambar 6 terlihat bahwa persentase dekolorisasi kongo merah mencapai kondisi optimum pada $\mathrm{pH} 4$ dengan persentase dekolorisasi sebesar $98,87 \%$. Hal ini menunjukkan bahwa degradasi zat warna kongo merah mencapai kondisi optimum pada $\mathrm{pH}$ asam. Hal ini terjadi karena pada $\mathrm{pH}$ yang tinggi (basa) hidrogen peroksida akan terdekomposisi menjadi $\mathrm{H}_{2} \mathrm{O}$ dan $\mathrm{O}_{2}$. Besi dalam suasana asam lebih mudah teroksidasi dibandingkan dalam suasana basa. Semakin banyak besi yang teroksidasi, maka semakin banyak $\mathrm{H}_{2} \mathrm{O}_{2}$ yang tereduksi menjadi radikal $\mathrm{OH}$. Semakin banyak radikal $\mathrm{OH}$ yang terbentuk, maka semakin banyak zat warna terdegradasi (Peters et al., 2001).

\section{Penentuan Konsentrasi $\mathrm{H}_{2} \mathrm{O}_{2} \mathrm{Optimum}$}

Penentuan konsentrasi $\mathrm{H}_{2} \mathrm{O}_{2}$ optimum dilakukan dengan memvariasikan konsentrasi $\mathrm{H}_{2} \mathrm{O}_{2}$ pada voltase, jarak elektroda, dan $\mathrm{pH}$ optimum. Konsentrasi $\mathrm{H}_{2} \mathrm{O}_{2}$ optimum untuk mendekolorisasi kongo merah seperti terlihat pada Gambar 7.

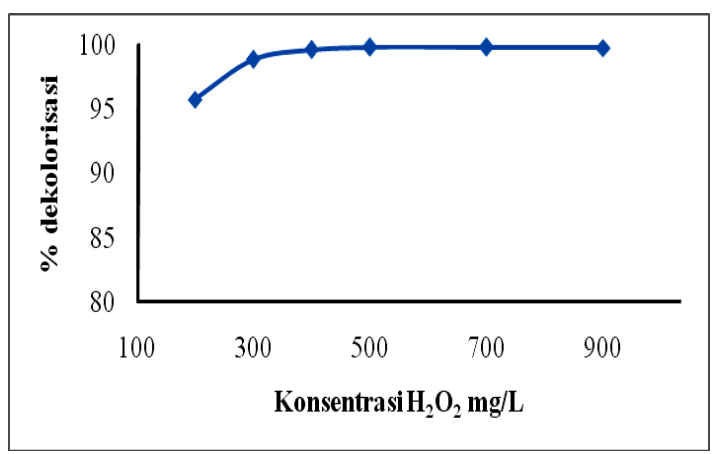

Gambar 7. Grafik pengaruh konsentrasi $\mathrm{H}_{2} \mathrm{O}_{2}$ terhadap \% dekolorisasi kongo merah 
Berdasarkan Gambar 7 terlihat bahwa konsentrasi $\mathrm{H}_{2} \mathrm{O}_{2}$ optimum adalah $500 \mathrm{mg} / \mathrm{L}$ dengan persentase dekolorisasi sebesar 99,90\%. Hal ini menunjukkan bahwa pembentukan radikal $\mathrm{OH}$ dari $\mathrm{H}_{2} \mathrm{O}_{2}$ mencapai keadaan maksimum sehingga radikal $\mathrm{OH}$ yang dihasilkan dapat mendegradasi zat warna kongo merah secara maksimal.

\section{Penentuan Persentase Dekolorisasi Sampel Limbah Cair Tekstil}

Limbah cair industri tekstil terutama dihasilkan dari proses pewarnaan (dyeing). Limbah cair yang dihasilkan dari proses ini menyebabkan pencemaran lingkungan karena dibuang ke badan perairan tanpa pengolahan terlebih dahulu. Badan perairan tidak mampu mendegradasi zat warna tersebut sehingga daerah aliran sungai menjadi berwarna dan tidak dapat mendukung sistem kehidupan perairan.

Zat warna reaktif merupakan zat warna yang banyak digunakan untuk pewarnaan tekstil (Robinson et al., 2001). Kongo merah merupakan salah satu zat warna reaktif yang sering digunakan industri tekstil. Zat warna tersebut sangat larut dalam air dan tidak dapat terdegradasi secara biologi (recalcitrance) (Catanho, 2006). Oleh karena itu, suatu teknik yang efektif dan efisien untuk mendegradasi zat warna tersebut sangat dibutuhkan segera. Suatu metode degradasi zat warna kongo merah limbah cair industri tekstil yang lebih efektif, efisien dan murah telah dikembangkan, yaitu metode elektrodekolorisasi.

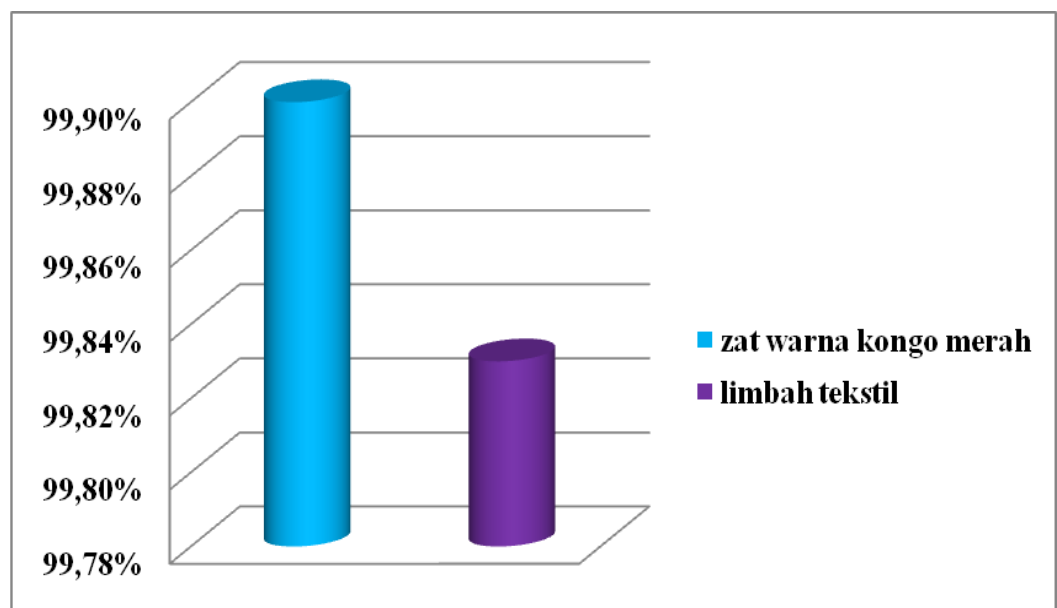

Gambar 8. Grafik dekolorisasi kongo merah limbah cair tekstil

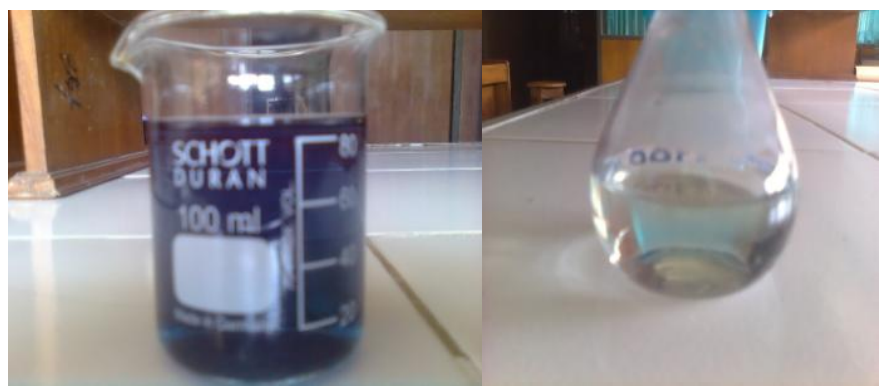

(a)

(b)

Gambar 9. Foto limbah cair tekstil sebelum dielektrodekolorisasi (a) dan setelah dielektrodekolorisasi (b) 
Dekolorisasi zat warna kongo merah limbah cair tekstil ini dilakukan pada voltase 12 volt, waktu 12 menit, jarak elektroda $1 \mathrm{~cm}, \quad \mathrm{pH} 4$ dan konsentrasi $\mathrm{H}_{2} \mathrm{O}_{2} \quad 500 \mathrm{mgL}^{-1}$. Hasil pengukuran seperti terlihat pada pada Gambar 8.

Berdasarkan Gambar 8 terlihat bahwa penurunan persentase dekolorisasi zat warna kongo merah dalam limbah cair tekstil sangat signifikan yaitu $99,83 \%$. Secara visual juga terlihat warna limbah cair tekstil menjadi bening setelah proses elektrodekolorisasi seperti pada Gambar 9.

\section{KESIMPULAN}

Berdasarkan hasil penelitian dapat disimpulkan bahwa zat warna kongo merah limbah cair industri tekstil dapat didegradasi hingga 99,83\% pada voltase $12 \mathrm{~V}$, waktu 12 menit, jarak elektroda 1 $\mathrm{cm}, \mathrm{pH} 4$ dan konsentrasi $\mathrm{H}_{2} \mathrm{O}_{2} 500 \mathrm{mg} / \mathrm{L}$ dengan menggunakan metode elektrodekolorisasi.

\section{DAFTAR PUSTAKA}

Catanho, M., 2006, Avaliacao Dos Tratamentos Eletroquimico Fotoeletroquimico Na Degradacao De Corantes Texteis, Quim.Nova, Vol 29, No.5.

Gupta,V.K., R., Jain, \& S.,Varshney, 2007, Electrochemical Removal of the Hazardous Dye Reactofix Red 3 BFN from Industrial Effluents, Journal of Colloid and Interface Science, Vol 312, No.2, 292-296

Ibanez, G.J., 1998, Electrochemical Remediation of The Enviroment Fundamentals and Microscale Laboratory Experiment, Chemical
Education, Vol. 75, No. 8, 1040-1041

Mondal, S., 2008, Methods of Dye Removal from Dye House Effluent, Ellis Horwood Limited, Chichester

Pala, A., E., Tokat, \& H., Erkayu, 2003, Removal of Some Reactive Dyes From Textile Processing Waste Water Using Powdered Activated Carbon, Proceeding of The First International Conference on Enviromental Research and Assesment, Bucharest, Rumania

Peters, S.M., T.T., Wong, \& J.H., Agar, 2001, A laboratory Study on The Degradation of Gasoline Contamination Using Fenton Reagent, Proceding $54^{\text {th }}$ Canadian Geotechnical Conference, Calgary, 1170-1177.

Rashed, M.N. \& A.A., El-Amin, 2007, Photocatalytic Degradation of Metil Orange in Aqueos $\mathrm{TiO}_{2}$ Under Different Solar Irradiation Source, Int.J.Physical.Sci, Vol 2, No. 3, 73-81

Skoog, D.A, D.M., West, F.J., Holler, \& S.R., Crouch, 2004, Fundamentals of Analytical Chemistry, $8^{\text {th }}$ Edition, Thomson Learning Inc, United States of America.

Suprijono, 2004, Degradasi Anilin dengan Reagen Fenton, Jurnal IPTEK, Vol 7, No. 2, Surabaya.

Suyata, D.W., Dwiasi, Irmanto, \& M., Kurniasih, 2010, Studi Optimasi Elektrodekolorisasi Zat Warna Proksion Merah Mx-8B, Laporan Penelitian, Fakultas Sains dan Teknik Unsoed, Purwokerto 